\title{
HEALTH RISKS OF NITROGEN DIOXIDE EXPOSURE AMONG PRIMARY SCHOOL CHILDREN IN OGAN ILIR, SOUTH SUMATRA, INDONESIA: EFFECT ON LUNG FUNCTION
}

\author{
Elvi Sunarsih, Harun Alrasid, Imelda Gernauli Purba, Inoy Trisnaini \\ Public Health Faculty, Sriwijaya University
}

\begin{abstract}
Nitrogen dioxide $\left(\mathrm{NO}_{2}\right)$ is one of the most dangerous air pollutants as regards human health. Increased traffic volumes on the east-lane roadside of South Sumatra have led to increased $\mathrm{NO}_{2}$ concentrations. In terms of age and $\mathrm{NO}_{2}$, children are the greatest risk group. The aim of this research was to estimate health risks of $\mathrm{NO}_{2}$ and analyze the correlation between exposure and lung capacity. This was an analytical study, with a cross-sectional design and risk analysis. The study group consisted of 100 children of primary school age. The results showed that the noncancer hazard index (HI)for $\mathrm{NO}_{2}$ exposure based on real-time data was 1.138. In the study population, as shown by the noncancer HI, $22 \%$ of students in OganIlir were classified as not at risk $(H I<1)$, whereas $78 \%$ were classified as at risk $(H I \geq 1)$. According to the results of simple linear regression, FEVI (Pearson's test: 0.0001) and FVC (Pearson's test: 0.0001) showed a significant correlation with noncancer $\mathrm{NO}_{2}$ risk. The results of simulations suggested that a value of $0.176 \mathrm{mg} / \mathrm{m}^{3} \mathrm{can}$ be used as a quality standard recommendation (health advisory) for $\mathrm{NO}_{2}$ exposure in roadside schools, especially schools abutting inter-provincial roads in South Sumatra.
\end{abstract}

Keywords: Nitrogen dioxide exposure, lung function, primary school studen, Ogan Ilir

\begin{abstract}
ABSTRAK
Nitrogen dioksida (NO2) adalah salah satu polutan udara paling berbahaya dalam hal kesehatan manusia. Volume lalu lintas yang meningkat di sisi timur-jalur jalan Sumatera Selatan telah menyebabkan peningkatan konsentrasi NO2. Dalam hal usia dan NO2, anak-anak adalah kelompok risiko terbesar. Tujuan dari penelitian ini adalah untuk memperkirakan risiko kesehatan NO2 dan menganalisis korelasi antara paparan dan kapasitas paru-paru. Penelitian ini menggunakan studi analiti, dengan desain cross-sectional dan analisis risiko. Kelompok studi terdiri dari 100 anak usia sekolah dasar. Hasil penelitian menunjukkan bahwa indeks bahaya non-kanker (HI) untuk paparan NO2 berdasarkan data real-time adalah 1,138. Dalam populasi penelitian, seperti yang ditunjukkan oleh noncancer HI, 22\% siswa di Ogan Ilir diklasifikasikan sebagai tidak berisiko ( $\mathrm{HI}<1$ ), sedangkan $78 \%$ diklasifikasikan sebagai berisiko $(\mathrm{HI} \geq 1$ ). Menurut hasil regresi linier sederhana, FEV1 (uji Pearson: 0,0001) dan FVC (uji Pearson: 0,0001) menunjukkan korelasi yang signifikan dengan risiko NO2 yang bukan kanker. Hasil simulasi menunjukkan bahwa nilai 0,176 mg / m3 dapat digunakan sebagai rekomendasi standar kualitas (penasehat kesehatan) untuk paparan NO2 di sekolah pinggir jalan, terutama sekolah berbatasan dengan jalan antar provinsi di Sumatera Selatan.
\end{abstract}

Kata kunci: Paparan nitrogen dioksida, fungsi paru-paru, siswa sekolah dasar, Ogan Ilir 


\section{INTRODUCTION}

The growth rate in the number of vehicles on Indonesian roads has increased significantly in recent years, rising throughout 2009, 2010, and 2011 to 67,290,816 units, 77,170,306 units, and $85,601,351$ units, respectively. By 2012, the number of motor vehicles in Indonesia was almost $50 \%$ greater than that in $2008 .^{1}$

The increase in the number of vehicles has knock-on effects on vehicle exhaust emissions levels. According to the U.S. EPA, the six most common types of air pollutants are ozone, particulate matter, carbon monoxide, nitrogen oxide $\left(\mathrm{NO}_{\mathrm{x}}\right)$, sulfur dioxide $\left(\mathrm{SO}_{2}\right)$, and Plumbum $(\mathrm{Pb})^{2}$. Approximately $50 \%$ of $\mathrm{NO}_{\mathrm{x}}$ emissions are generated by vehicles. ${ }^{2}$ Exposure to air pollution can result in chronic or acute conditions. In the short term, air pollutant gases $(\mathrm{Pb}$, nitrogen dioxide $\left[\mathrm{NO}_{2}\right], \mathrm{SO}_{2}, \mathrm{TSP}$, and dust) can cause respiratory disorders, such as bronchopneumonia, pulmonary edema, cyanosis, and methemoglobinemia, resulting inweakness, coughing, and shortness of breath. ${ }^{3}$

Air pollution not only has serious consequences for large cities in developing countries but also for suburban areas in close proximity to cities and provincial traffic routes. ${ }^{4}$ Schools located on the edge of the road cross country and provinces have a greater risk than schools on the roadside, with good school facilities. ${ }^{3}$ The aim of this study was to predict the health effects of exposure to $\mathrm{NO}_{2}$ by calculating noncancer hazard index (HI) scores, the prevalence of lung function disorders, and the correlation between these parameters in primary school students in OganIlir, South Sumatra. ${ }^{5}$ The aim of this research was to estimate health risks of $\mathrm{NO}_{2}$ and analyze the correlation between exposure and lung capacity.

\section{METHOD}

We conducted a risk analysis to predict the level of health risks from exposure to $\mathrm{NO}_{2}$ among at-risk populations. The respondents were primary school students attending roadside schools in south-eastern Sumatra. The risk characteristics of noncancer were expressed by the noncancer hazard index (HI), which was based on reference concentration (RfC) values forNO exposure, anthropometric data (inhalation rate and weight), and patterns of exposure (time, frequency, and duration of exposure $\mathrm{NO}_{2}$ ). ${ }^{6}$ The $\mathrm{HI}$ score was based on a comparison of intake with RfC where the intake was the result of the calculation of exposure assessment. This study used a cross-sectional design to test the correlation of health risk prediction scores with $\mathrm{NO}_{2}$ status, lung capacity, and respiratory disorders. ${ }^{7}$

The study was conducted in four stages. The first stage consisted of a preliminary survey and observations in the study population for the data of risk assessment. The second stage comprised 
spirometry measurements and air sample data collection. The third stage consisted of a laboratory analysis and spirometry analysis. The fourth stage involved characterization of the health risks, modeling of health risk factors, and simulating risk control models.

The location of this research was OganIlir, South Sumatra Province, Indonesia. We examined $\mathrm{NO}_{2}$ air quality in 10 primary schools $(n=568$ schoolchildren) located at roadsides, including a population at risk located at the edge of East Cross Street, OganIlir, South Sumatra. Sampling was done by the proportionate stratified random sampling method. The sampling unit was a primary school located on the east side of the road $(<5 \mathrm{~m})$.

The minimum sample size in this study was calculated using the application named sample size 2.0. Based on the population size in the study $(n=568)$, the minimum sample size was calculated as 78.88 , rounded to 80 respondents. However, to avoid loss to follow-up or drop outs from the samples, a minimum sample size will be added as much as $20 \%$ (i.e., 16 respondents). Thus, the minimum total sample required in this study was $n=96$. Therefore, the field of samples to be taken was completed, so the total sample was 100 respondents.

In this study, the districts were selected as a subpopulation. There are 298 primary schools in 15 districts of OganIlir. Ten of these schools were selected, and the required sample size was determined proportionally.

In this study, the score of confidence interval z 1- $\alpha / 2$ hypothesis test two-way (two-tailed) was 1.96, with minimal error for health research 0.1 . The proportion of the incidence of respiratory disorders (lung capacity function) was based on research ${ }^{8,9}$ on respiratory disorders in primary schoolchildren in Palembang was 0.389 .

In each school, $\mathrm{NO}_{2}$ was measured once for $1 \mathrm{~h}$ at 12:00 $\mathrm{h}$. The measurements were obtained using a spectrometer (SNI 19-7119.2-2005 Saltman Griess) ${ }^{9}$. The following materials and tools were used in the analysis of the concentration of $\mathrm{NO}_{2}$ : a spectrophotometer, absorb $\mathrm{NO}_{2}, \mathrm{NO}_{2}$ standard solution, and Aqua Bidest. The spectrophotometric analysis of $\mathrm{NO}_{2}$ was conducted in the laboratory of Hiperkes, Plaju, Palembang, South Sumatra. ${ }^{10}$

\section{RESULTS}

$\mathrm{NO}_{2}$ concentration levels among primary school students ranged from $0.182 \mathrm{mg} / \mathrm{m}^{3}$ to 0.222 $\mathrm{mg} / \mathrm{m}^{3}$, with an average of $0.2004 \mathrm{mg} / \mathrm{m}^{3}$. The distribution of $\mathrm{NO}_{2}$ concentrations in the different primary schools is shown in table 1 . 
Table 1. $\mathrm{NO}_{2}$ concentration in the School

\begin{tabular}{lc}
\hline \multicolumn{1}{c}{ Schools } & NO $_{2}$ concentration $\left(\mathbf{m g} / \mathbf{m}^{\mathbf{3}}\right)$ \\
\hline SD N 05 Indralaya & 0.2005 \\
SD N 02 Indralaya & 0.2215 \\
SD N 06 Indralaya & 0.2220 \\
SD N 25 TalangBalaiBaru & 0.1925 \\
SD N 2 Srijabo & 0.1925 \\
SD N 02 Indralaya Utara & 0.2015 \\
SD N 20 Tanjung Raja & 0.1922 \\
SD N 06 Tanjung Raja & 0.2012 \\
SD N 01 Tanjung Raja & 0.2015 \\
SD N 11 Tanjung Raja & 0.1820 \\
\hline
\end{tabular}

Risk characteristics were determined based on an exposure assessment and dose-response assessment. The exposure analysis determined the value of inhalation intake. To determine the data needed dose intake of the risk agent, exposure pathway, exposure frequency, and duration of exposure. $\mathrm{NO}_{2}$ exposure in this study through inhalation. The exposure time (h/day) of each student was obtained by calculating the difference of school time after leaving school. The average exposure time was $5.53 \mathrm{~h} /$ day, with a minimum exposure time of $4.7 \mathrm{~h} /$ day. The longest exposure time was $6 \mathrm{~h} /$ day. The frequency of exposure (days/year) was obtained by calculating the difference between the number of days per year and number of days in the academic calendar of primary schools in OganIlir. The frequency of exposure was 264 days/year. Then, the duration of exposure for 3 years to grade IV. The following anthropometry data were obtained: student's body weight and inhalation rate. The results of weight measurements of the students are presented in Table 2.

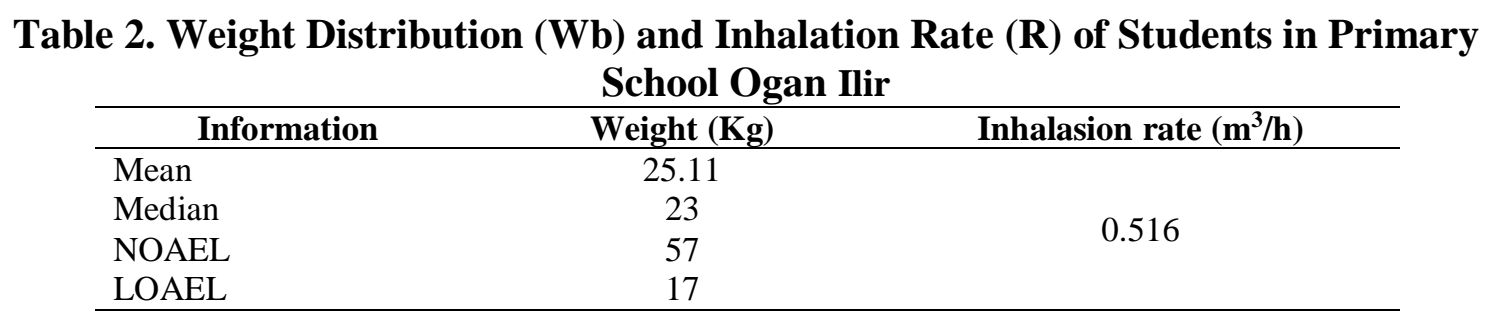

The average weight of the respondents was $25.11 \mathrm{~kg}$, with a lowest weight of $17 \mathrm{~kg}$ and highest weight of $57 \mathrm{~kg}$. The rate of inhalation was calculated according to U.S. Environmental Protection Agency (EPA) standards for long-term exposure among those aged 6-11 years. The recommended rate of inhalation was $12.4 \mathrm{~m}^{3} / \mathrm{day}$. After converting, the inhalation rate per hour was $0.516 \mathrm{~m}^{3} /$ hour and used in this study. In the exposure analysis, inhalation intake (I) was calculated using the following formula:

$$
\mathrm{I}=\frac{\mathrm{CRt}_{\mathrm{e}} \mathrm{f}_{\mathrm{e}} \mathrm{D}_{\mathrm{t}}}{\mathrm{W}_{\mathrm{b}} \mathrm{t}_{\mathrm{avg}}}
$$


To calculate real-time $\mathrm{NO}_{2}$ intake of students attending primary schools on the east side of the road, average exposure data were used, as below:

\section{Data exposure pattern}

$\mathrm{NO}_{2}$ Concentration

$$
=0.2004 \mathrm{mg} / \mathrm{m}^{3}
$$

Inhalation Rate (R)

$=0.516 \mathrm{~m}^{3} / \mathrm{hour}$

Duration of Exposure (hours/day)

$=5.53$ hours/day

Frequency (days/year)

$=264$ days/year

Duration (years)

$=3$ years

Weight $\left(\mathrm{W}_{\mathrm{b}}\right)$

$=25.11 \mathrm{~kg}$

Mean Period $\left(\mathrm{t}_{\text {avg }}\right)$

$=3 \times 264$ days $=792$ days

$$
\text { Intake }(\mathrm{I})=\frac{0,2004 \times 0,516 \times 5,53 \times 264 \times 3}{25,11 \times 792}
$$

$$
=0.023 \mathrm{mg} / \mathrm{kg} \cdot \mathrm{day}
$$

Table 3 presents the distribution of $\mathrm{NO}_{2}$ inhalation intake for each of the respondents. The lowest inhalation intake was $0.01 \mathrm{mg} / \mathrm{kg}$.hari, and the highest intake was $0.04 \mathrm{mg} / \mathrm{kg}$.hari.

Table 3. Inhalation Intake Distribution $\mathrm{NO}_{2}$ of Students in Primary School OganIlir

\begin{tabular}{lc}
\hline \multicolumn{1}{c}{ Information } & Inkate $\mathbf{N O}_{2}$ ( $\left.\mathbf{m g} / \mathbf{k g . h a r i}\right)$ \\
\hline Mean & 0.0241 \\
Median & 0.0246 \\
LOAEL & 0.01 \\
NOAEL & 0.04 \\
\hline
\end{tabular}

The quantitative values required for the toxicity risk characteristics were NOAEL or LOAEL derived from bioassay testing and epidemiological studies. In this study, the reference concentration (RfC) value for $\mathrm{NO}_{2}$ was the U.S. EPA standard of $0.02 \mathrm{mg} / \mathrm{kg} / \mathrm{day} .{ }^{11}$

Risk characteristics were obtained from an assessment of exposure and dose-response assessment. The average HI for real-time exposure was $1.138(\geq 1) .{ }^{12}$

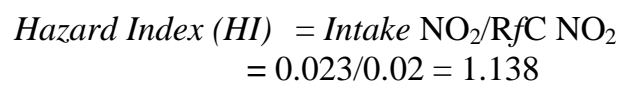


Table 4. Calculation of Risk Non Cancer (HI) Realtime $\mathrm{NO}_{2}$ of Students in Primary School OganIlir

\begin{tabular}{|c|c|c|c|c|}
\hline \multirow{3}{*}{ Information } & \multicolumn{4}{|c|}{ Non Cancer Risk } \\
\hline & \multicolumn{2}{|c|}{ HI $<1$} & \multicolumn{2}{|c|}{$H \geq 1$} \\
\hline & $\mathbf{n}$ & $\%$ & $\mathrm{n}$ & $\%$ \\
\hline Male & 10 & 45,5 & 43 & 55,1 \\
\hline Female & 12 & 54,5 & 35 & 44,9 \\
\hline Total & 22 & 100 & 78 & 100 \\
\hline
\end{tabular}

As shown by the HI calculations for each respondent, most of the students had a HI value $\geq$ 1: $78 \%$ group of boys with 43 respondents and $35 \%$ of girls. ${ }^{13}$ It can be concluded that $\mathrm{NO}_{2}$ exposure among primary school students attending roadside schools represents a noncancer health risk. Thus, $\mathrm{NO}_{2}$ exposure needs to be controlled.

Table 5. Correlation of FEV1 with noncancer $\mathrm{NO}_{2}$ risk

\begin{tabular}{|c|c|c|c|}
\hline \multirow[b]{2}{*}{ Variable } & \multicolumn{3}{|c|}{ Correlation of FEV1 with noncancer $\mathrm{NO}_{2}$ risk } \\
\hline & $\begin{array}{l}\text { Normalitas test } \\
\quad(p>0,05)\end{array}$ & Pearsons test $(\mathrm{p}<0,05)$ & $\begin{array}{c}\text { Linear regretion (fit } \\
\text { all model) }\end{array}$ \\
\hline FEV1 & 0,200 & 0,0001 & 0,0001 (parsial) \\
\hline HI & 0,092 & 0,0001 & 0,0001 (parsial) \\
\hline
\end{tabular}

The relationship of FEV1 value with the estimated non-cancer risk of $\mathrm{NO}_{2}$ will be tested using Pearson correlation and simple linear regression. The results of the analysis of the relationship between the value of the lung capacity of FEV1 and the estimated non-cancer risk of NO2 showed that there was a significant relationship $(p<0.05)$ between the lung capacity of FEV1 and the estimated risk of non-cancerous $\mathrm{NO} 2$

Table 6. Correlation of $\mathrm{FVC}$ with noncancer $\mathrm{NO}_{2}$ risk

\begin{tabular}{lccc}
\hline \multirow{2}{*}{ Variable } & \multicolumn{3}{c}{ Correlation of FVC with noncancer $\mathbf{N O}_{2}$ risk } \\
\cline { 2 - 4 } & $\begin{array}{c}\text { Normalitas test } \\
(\mathbf{p}>\mathbf{0 , 0 5})\end{array}$ & Pearsons test $(\mathbf{p}<\mathbf{0 , 0 5})$ & $\begin{array}{c}\text { Linear regretion (fit } \\
\text { all model) }\end{array}$ \\
\hline FVC & 0,175 & 0,0001 & 0,0001 (parsial) \\
HI & 0,092 & 0,0001 & 0,0001 (parsial) \\
\hline Pers. & \multicolumn{3}{c}{ Nilai FEV1 $=2,268-0,619 \mathrm{HI}$} \\
\hline
\end{tabular}

The results of the analysis of the relationship between the value of FVC lung capacity with estimated non-cancer risk of $\mathrm{NO}_{2}$ showed that there was a significant relationship $(\mathrm{p}<0.05)$ between $\mathrm{FVC}$ lung capacity and estimated non-cancer risk of $\mathrm{NO}_{2}$. 
Table 7. Relationship between Lung Function Disorders and Respiratory Complaints

\begin{tabular}{|c|c|c|c|c|c|c|c|}
\hline \multirow{2}{*}{\multicolumn{2}{|c|}{$\begin{array}{l}\text { Respiratory Tract } \\
\text { Complaints }\end{array}$}} & \multicolumn{4}{|c|}{ Obstruction Status (\%FEV1/FVC) } & \multirow{4}{*}{$\begin{array}{c}\begin{array}{c}\text { Odds Ratio } \\
\text { (95\% CI) }\end{array} \\
0,909 \\
(0,348-2,377)\end{array}$} & \multirow{4}{*}{$\begin{array}{r}\text { Sign. } \\
\mathrm{P}>0,05\end{array}$} \\
\hline & & \multirow{2}{*}{$\begin{array}{c}\text { Yes }(<75) \\
20\end{array}$} & \multirow{2}{*}{$\frac{\mathrm{No}(\geq 75)}{50}$} & \multirow{2}{*}{$\frac{\mathbf{n}}{70}$} & \multirow{3}{*}{$\begin{array}{l}\% \\
70 \\
30\end{array}$} & & \\
\hline Dry cough & Yes & & & & & & \\
\hline & No & 8 & 22 & 30 & & & \\
\hline \multirow{2}{*}{$\begin{array}{l}\text { Cough with } \\
\text { phlegm }\end{array}$} & Yes & 17 & 42 & 59 & 59 & \multirow{2}{*}{$\begin{array}{c}0,906 \\
(0,371-2,209)\end{array}$} & \multirow{2}{*}{$\mathrm{P}>0,05$} \\
\hline & No & 11 & 30 & 41 & 41 & & \\
\hline \multirow[t]{2}{*}{ Wheezing } & Yes & 5 & 9 & 14 & 14 & \multirow{2}{*}{$\begin{array}{c}0,657 \\
(0,199-2,166)\end{array}$} & \multirow{2}{*}{$\mathrm{P}>0,05$} \\
\hline & No & 23 & 63 & 86 & 86 & & \\
\hline \multirow{2}{*}{$\begin{array}{l}\text { Shortness of } \\
\text { breath }\end{array}$} & Yes & 7 & 17 & 24 & 24 & \multirow{2}{*}{$\begin{array}{c}0,927 \\
(0,336-2,555)\end{array}$} & \multirow{2}{*}{$\mathrm{P}>0,05$} \\
\hline & No & 21 & 55 & 76 & 76 & & \\
\hline \multirow{2}{*}{\multicolumn{2}{|c|}{$\begin{array}{l}\text { Respiratory Tract } \\
\text { Complaints }\end{array}$}} & \multicolumn{4}{|c|}{ Restriction Status (\%FVC/FVCPredict) } & \multirow{2}{*}{$\begin{array}{c}\text { Odds Ratio } \\
\text { (95\% CI) }\end{array}$} & \multirow{2}{*}{ Sign. } \\
\hline & & Yes $(<80)$ & $\operatorname{No}(\geq 80)$ & $\mathbf{n}$ & $\%$ & & \\
\hline \multirow{2}{*}{ Dry cough } & Yes & 4 & 66 & 70 & 70 & \multirow{2}{*}{$\begin{array}{c}5,022 \\
(1,346-18,74)\end{array}$} & \multirow{2}{*}{$\mathrm{P}<0,05$} \\
\hline & No & 7 & 23 & 30 & 30 & & \\
\hline \multirow{2}{*}{$\begin{array}{l}\text { Cough with } \\
\text { phlegm }\end{array}$} & Yes & 5 & 54 & 59 & 59 & \multirow{2}{*}{$\begin{array}{c}1,851 \\
(0,525-6,532)\end{array}$} & \multirow{2}{*}{$\mathrm{P}>0,05$} \\
\hline & No & 6 & 35 & 41 & 41 & & \\
\hline \multirow[t]{2}{*}{ Wheezing } & Yes & 1 & 13 & 14 & 14 & \multirow{2}{*}{$\begin{array}{c}1,711 \\
(0,202-14,512)\end{array}$} & \multirow{2}{*}{$\mathrm{P}>0,05$} \\
\hline & No & 10 & 76 & 86 & 86 & & \\
\hline \multirow{2}{*}{$\begin{array}{l}\text { Shortness of } \\
\text { breath }\end{array}$} & Yes & 3 & 21 & 24 & 24 & \multirow{2}{*}{$\begin{array}{c}0,824 \\
(0,200-3,387)\end{array}$} & \multirow{2}{*}{$\mathrm{P}>0,05$} \\
\hline & No & 8 & 68 & 76 & 76 & & \\
\hline
\end{tabular}

Complaints of respiratory distress felt by elementary school students who are on the edge of the eastern crossing highway in the past month is a dry cough, cough with phlegm, wheezing, and shortness of breath. There are two types of lung function disorders analyzed with respiratory complaints, namely obstruction status (\% FEV1/FVC) and restriction status (\% FVC/FVC Predict). Someone said to have pulmonary obstruction if the percentage value of the FEV1 to FVC ratio is less than $75 \%$. And someone is said to have pulmonary restriction if the percentage value of FVC to FVC prediction is less than $80 \%$. From the results of the analysis using the Chi-square test it was found that there was a significant relationship $(\mathrm{p}<0.05)$ between restriction status with complaints of dry cough where the oddsratiowas 5.002.

$$
C=\frac{I \cdot W_{b \cdot t_{a v g}}}{R \cdot t_{e} \cdot f_{e} D_{t}}=\frac{0,020 \times 25,11 \times 264 \times 3}{0,516 \times 5,53 \times 264,3 \times 3}=0,176
$$

The results of the calculation of $0.176 \mathrm{mg} / \mathrm{m} 3$ can be used as a standard quality recommendation (health advisory) for the roadside school environment, especially cross-provincial roads. If you see the results of measurements of concentration in 10 elementary schools that have been carried out then all elementary schools require control because all NO2 concentrations in the school environment are above the recommended concentration (>0.176 mg / m3). Only SD 20 Tanjung Raja and SD N 11 Tanjung Raja are approaching. This could be due to the orientation of 
the building of SD N 20 not facing the east (back) road and SD N 11 Tanjung Raja having a beautiful environment full of green trees.

\section{DISCUSSION}

The risk analysis showed that the need for risk management was greater in the presence of a $\mathrm{HI}$ value $>1$. The results indicate that risk management is required in the study area to control health-related effects of $\mathrm{NO}_{2}$. Such control can be achieved by modifying standards or quality standards. ${ }^{14,15}$ The RfC value is a reference value derived from experimental data and therefore cannot be modified. The $\mathrm{HI}$ value $>1$ can be controlled by controlling the intake value (I) of $\mathrm{NO}_{2}$ inhalation.The value has to be lowered to I to make it harmless. In the present study, the mean intake value was 0.0236 , and the highest value was 0.04 . To decrease the intake value to an acceptable RfC level (i.e., 0.02), we can use the noncancer risk analysis equation. If at this time, the respondents in 4th grade are more or less than 3 years, the respondents exposed $\mathrm{NO}_{2}$ with the assumption for 3 did not change school. The present study assumed that there were no interventions to existing risks. Based on a mean concentration of $\mathrm{NO}_{2}$ of $0.2004 \mathrm{mg} / \mathrm{m}^{3}$ in primary schools in OganIlir and an annual rise in this concentration according to a 5\% increase in the rate of vehicular traffic (considering trends in growth rates based on data from the Central Statistics Agency 1987-2013) total exposure is considered constant at an mean value of $5.53 \mathrm{~h} /$ day. The inhalation rate using a default value of $0.516 \mathrm{~m}^{3} / \mathrm{h}$, frequency of school days of 264 days, and mean weight of subjects of $25.11 \mathrm{~kg}$. Table 4 shows the results of the first simulation model of exposure among 3rd to 6 th year students. ${ }^{16-18}$

Table 8. Estimated Hazard Index and Lung Capacity

\begin{tabular}{ccccc}
\hline \multicolumn{5}{c}{ Hazard Index Projection (Subchronic) } \\
\hline & $\mathbf{3}^{\text {rd }}$ Year & $\mathbf{4}^{\text {th }}$ Year & $\mathbf{5}^{\text {th }}$ Year & $\mathbf{6}^{\text {th }}$ Year \\
\hline Concentration NO & 0.2004 & 0.21042 & 0.220941 & 0.231988 \\
R & 0.516 & 0.516 & 0.516 & 0.516 \\
tE & 5.53 & 5.53 & 5.53 & 5.53 \\
f & 264 & 264 & 264 & 264 \\
D & 3 & 4 & 5 & 6 \\
Wb & 25.11 & 25.11 & 25.11 & 25.11 \\
I & 0.023 & 0.0239 & 0.0251 & 0.02636 \\
RfC & 0.02 & 0.02 & 0.02 & 0.02 \\
HI & 1.138 & 1.195 & 1.255 & 1.318 \\
\hline
\end{tabular}

$\mathrm{NO}_{2}$ appears to affect the lung layer by directly causing inflammation and indirectly damaging the immune defense mechanism. People with asthma, respiratory diseases, and chronic inflammation, such as chronic bronchitis, are susceptible, especially children. ${ }^{13}$ A study conducted in New Zealand reported an association between indoor $\mathrm{NO}_{2}$ and lung function (FEV1) of children with asthma, with lung function decreased in the presence of increased $\mathrm{NO}_{2}$ levels indoors in mornings and afternoons during the wintertime ${ }^{19}$. Research conducted in Bandung, Indonesia 
revealed a significant relationship (0.001) between the distances of houses from roadsides and $\mathrm{NO}_{2}$ concentrations inside the house, with houses at greater distances from roadsides having reduced $\mathrm{NO}_{2}$ values. ${ }^{14}$ The mean $\mathrm{NO}_{2}$ value at the roadside over a 1-week period was $0.432 \mathrm{mg} / \mathrm{m}^{3}$. The findings of the study in Bandung were similar to those of a study of 39 primary schools in Barcelona, Spain. ${ }^{20}$ In the study, the average $\mathrm{NO}_{2}$ concentration in a school environment (outdoor) was $0.41 \mathrm{mg} / \mathrm{m}^{3}$. A cohort study of 4th-, 7th-, and 10thgrade children in southern California revealed a significant relationship between decreased lung capacity (FEV1, FVC, maximal midexpiratory flow, and FEF75) and exposure to $\mathrm{PM}_{10}, \mathrm{PM}_{2.5}, \mathrm{PM}_{10}-\mathrm{PM}_{2.5}, \mathrm{NO}_{2}$, and inorganic acid gases $(P<0.05)$ in both healthy children and those with a history of asthma. ${ }^{21}$

Environmental factors, including the locations of houses, affect a person's lung capacity and exacerbate the effects of $\mathrm{NO}_{2}$. People living close to pollution sources (e.g., industrial estates and roadsides) are more susceptible to decreased lung capacity than those living in areas far from pollution sources. A study of lung capacity function in a roadside population in Jalgaon City, India reported a decrease in lung capacity in store owners exposed to traffic pollution ${ }^{22}$. In the study, decreases in FEV1 and PEFR in the exposed group was more significant than those in a control group. The lung capacity of the FEV1/FVC group of controls was better than that of the cases, showing that the lung capacity of individuals not exposed to pollution was better than that of those exposed to pollution.

According to data from the Agency for Toxic Substances and Disease Registry, households that burned a large amount of wood or used kerosene heaters and gas stoves had higher $\mathrm{NO}_{2}$ levels inside their homes as compared with those without wood or kerosene heater use. ${ }^{23} \mathrm{NO}_{2}$, a byproduct of combustion produced by indoor gas appliances, such as cooking stoves, was associated with respiratory symptoms in individuals with obstructive airway disease. ${ }^{24}$ Home inspection and $\mathrm{NO}_{2}$ monitoring were conducted 1 week prior to interventions (i.e., stove replacement, air purifier installation, or ventilation hood installation) and 1 week and 3 months after the interventions. Stove replacement resulted in a $51 \%$ and $42 \%$ decrease in median $\mathrm{NO}_{2}$ concentrations 3 months postintervention in kitchens and bedrooms, respectively $(P=0.01, P=0.01)$. Air purifier placement resulted in an immediate decrease in median $\mathrm{NO}_{2}$ concentrations in kitchens $(27 \%, P<0.01)$ and bedrooms $(22 \%, P=0.02)$. However, 3 months post-intervention, a significant reduction in $\mathrm{NO}_{2}$ concentrations was found only in kitchens $(20 \%, P=0.05)$. $\mathrm{NO}_{2}$ concentrations in kitchens and bedrooms did not significantly change following ventilation hood installation. The study concluded that replacing unvented gas stoves with electric stoves or the placement of air purifiers with HEPA and carbon filters can decrease indoor $\mathrm{NO}_{2}$ concentrations in urban homes. 


\section{CONCLUSIONS}

The exposure HI using real-time data was 1.138 , with $78 \%$ of the study population at risk $(\mathrm{HI} \geq 1)$ and $22 \%$ not at risk $(\mathrm{HI}<1)$. The model prediction FEV1 by $\mathrm{HI}$ predictor $\mathrm{NO}_{2}$, and the FEV1 value was 1.869 to $0.543 \mathrm{HI}$. Thus, the value of the parameter FEV1 lung capacity can be predicted using the HI, where any increase in the value of 1 in the HI will be followed by a decline in FEV1 of $0.543 \mathrm{~L}$. Model FVC values were predicted by the predictor $\mathrm{HI} \mathrm{NO}_{2}$, and the FVC value was 2.268 to $0.619 \mathrm{HI}$. Thus, lung capacity FVC values can be predicted using the HI, where any increase in the value of 1 in the $\mathrm{HI}$ will be followed by a decline of $0.619 \mathrm{~L}$ in the FVC value. The present study revealed a significant relationship $(P<0.05)$ between the restriction status and complaints of a dry cough (odds ratio of 5.002). The most common complaints were a cough (70\%). Other respiratory complaints were not statistically significant, either on the status of obstruction or restriction status. The results suggested that a value of $0.176 \mathrm{mg} / \mathrm{m}^{3}$ can be used as a quality standard recommendation (health advisory) for $\mathrm{NO}_{2}$ exposure in roadside schools, especially schools abutting inter-provincial roads.

\section{REFERENCES}

1. Ministry of Health of the Republic of Indonesia. Parameter Pencemar Udara Dan Dampaknya Terhadap Kesehatan. 2011.

2. US EPA. Federal Register - Guidelines for Exposure Assessment; Notice. Washington, DC, US Environmental Protection Agency. 1992.

3. US EPA. Framework for Ecological Risk Assessment. Washington, DC, US Environmental Protection Agency. 1992.

4. Standar Nasional Indonesia (SNI). Udara ambien-bagian 7: Cara uji kadar nitrogen dioksida (NO2) denganmetoda Griess Saltzman menggunakan spektrofotometer. SNI 19-7119.2. 2005.

5. Pilotto, L.S., Douglas, R.M., Attewell, R.G and Wilson, S.R. Respiratory Effects Associated with Indoor Nitrogen Dioxide Exposure in Children. International Journal of Epidemiology. 1997; 26 (4): 788-796.

6. Jarvis D, Chinn S, Sterne J, Luczynska C, Burney O. Association of respiratory symptoms and lung function in young adults with use of domestic gas appliances. Lancet. 1998; 347:426- 431. 223.

7. Putri, A Retno dan Driejana. Analisis Konsentrasi NOx Di Dalam Ruangan Pada Rumah Tinggal Di Tepi Jalan Raya (Studi Kasus: Wilayah Karees, Bandung) [thesis]. Bandung: Institute Teknologi Bandung; 2012.

8. Handayani, Diah., Yunua, Faisal., Wiyono, W. Heru. Pengaruh Inhalasi $\mathrm{NO}_{2}$ Terhadap Kesehatan Paru. Jakarta: Cermin Dunia Kedokteran; 2003. 
9. Brauer M, Henderson S, Kirkham T, Shan Lee K, Rich K, Teschke K, 2020. Review of Health Risk Associated Nitrogen Dioxide and Sulfur Dioxide in Indoor Air [thesis]. Columbia: School of Occupational and Environmental Hygiene University of Brithis Columbia; 2002.

10. British Medical Council. Recommended Respiratory Disease Questionnaires for Usewith Adults and Children in Epidemiological Research. United Kingdom: British Medical Council ; 1978.

11. US EPA. Terms of Environment - Glossary, Abbreviations and Acronyms. Washington: US Environmental Protection Agency (EPA 175-B-93-001); 1993.

12. Warouw, Sony P. StudiAnalisisRisikoKesehatanPemajananKarsinogen Benzo (a) Pyrene Pada PetugasPintu Tol di JABODETABEK [thesis]. Depok: Program PascaSarjanaUniversitas Indonesia, Depok; 2007.

13. WHO. Air Quality Guidelines: Global Update 2005. Denmark: World Health Organization; 2006.

14. Driejana dan Novianti S. Pengaruh Karakteristik Faktor Emisi Terhadap Estimasi Beban Emisi Oksida Nitrogen (NOx) Dari Sektor Transportasi (StudiKasus: Wilayah Karees, Bandung) [thesis]. Bandung: Institute Teknologi Bandung; 2012.

15. United State Environmental Protection Agency. Human Health Risk Assessment. US-EPA; 1993.

16. Raharjo. Dampak Pencemaran Udara Pada Lingkungan Dan Kesehatan Manusia [thesis]. Semarang: Fakultas Kesehatan Masyarakat Universitas Diponegoro; 2009.

17. Rahman, Abdur. Public Health Assessment: Model Kajian Prediktif Dampak Lingkungan dan Aplikasinya Untuk Manajemen Risiko Kesehatan [thesis]. Jakarta: Fakultas Kesehatan Masyarakat Universitas Indonesia; 2005.

18. Jarvis DL, Leaderer BP, Chinn S, Burney PG, 2005. Indoor nitrous acid and respiratory symptoms and lung function in adults. Thorax. 2005: 60:474-479.

19. Bennett JG, Pierse N, Wickens K, Crane J, Chapman PH. The respiratory health effects of nitrogen dioxide $\left(\mathrm{NO}_{2}\right)$ in children with asthma. ERJ Express. 2010. doi: 10.1183/09031936.00115409.

20. Sunyer J, Esnaola M, Pedrerol MA, Forns J, Rivas I, Vicente ML, Gonzales ES, Foraster M, Esteban RG, Basagana X, Viana M, Cirach M, Moreno T, Alastuey A, Galles NS, Nieuwenhuijsen M, Querol X. Association between Traffic-Related Air Pollution in Schools and Cognitive Development in Primary School Children: A Prospective Cohort Study. Journal PMED. 2015. Doi: https://doi.org/10.1371/journal.pmed.1001792

21. Gauderman WJ, McConnell R, Gilliland F, London S, Thomas D, Avol E, Vora H, Berhane K, Rappaport EB, Lurmann F, Margolis HG, Peters J, 2000. Association between air pollution and 
lung function growth in southern California children. Am J Respir Crit Care Med. 2000;162(4):1383-90.

22. Sopan T INGLE, Nilesh WAGH. Impact Of Highway Traffic Pollution on Lung Function of Residential Population in Jalgaon Urban Center, India. 2005. http://www.iasi.cnr.it/ewgt/16conference/ID116.pdf

23. Agency for Toxic Substances and Disease Registry (ATSDR). Toxicological profile for Nitrogen Oxides (nitric oxide, nitrogen dioxide, etc). Atlanta : Department of Public Health and Human Services. Public Health Service; 2002.

24. Paulin LM, Diette GB, Scott M, McCormack MC, Matsui EC, Curtin-Brosnan J, Williams DL, Kidd-Taylor A, Shea M, Breysse PN, Hansel NN. Home interventions are effective at decreasing indoor nitrogen dioxide concentrations. International Journal of Indoor Environment and Health. 2014. DOI: 10.1111/ina.12085. 